\title{
KUALITAS PELAYANAN ADMINISTRASI PEMASANGAN LISTRIK BARU PADA PT. PLN (PERSERO) AREA MAKASSAR SELATAN
}

Siswati Rachman

Politeknik Informatika Nasional

sisrachman@gmail.com

\begin{abstract}
The purpose of this study is to determine the Quality of Administrative Services is applied in the Installation of New Electrical at PT. PLN (Persero) Area Makassar South. And find out the Constraints faced in providing Quality Administration Services Installation of New Electrical at PT. PLN (Persero) Area Makassar South. Type and design in this study uses descriptive quantitative, which describes the phenomenon of the quality of administrative services the installation of new electrical at PT. PLN (Persero) Area Makassar south. The results of the research show that the administrative Services are one of the types of services provided by PT.PLN (Persero) to the customer, which is of course a major concern of the company to maintain the company's image in the eyes of customers. Administrative services provided include administrative services the installation of new electrical, the addition of electrical power and electrical connections while. The whole of the process of providing administrative services, which allow contact Between customers and employees more and more, so that the administrative services rendered vulnerable to the complaint given to the customer due to dissatisfaction with the service provided. Customer dissatisfaction with the services provided, the course will have an adverse impact on the company. Therefore, to avoid such things, then the company should provide quality service. The indicators used to measure service quality are tangible, Reliability, Responsiveness, Assurance, Empathy.
\end{abstract}

Keywords : Quality, Service, Administration

\begin{abstract}
Abstrak
Tujuan penelitian ini untuk mengetahui Kualitas Pelayanan Administrasi yang diterapkan dalam Pemasangan Listrik Baru pada PT. PLN (Persero) Area Makassar Selatan. Dan mengetahui Kendalakendala apa saja yang dihadapi dalam memberikan Kualitas Pelayanan Administrasi Pemasangan Listrik Baru pada PT. PLN (Persero) Area Makassar Selatan. Jenis dan desain dalam penelitian ini menggunakan jenis deskriptif kuantitaif, yakni menggambarkan fenomena mengenai kualitas pelayanan administrasi pemasangan listrik baru pada PT. PLN (Persero) Area Makassar selatan. Hasil penelitan menunjukkan bahwa Pelayanan administrasi adalah salah satu jenis pelayanan yang diberikan PT.PLN (Persero) kepada pelanggan, yang tentu saja menjadi perhatian utama perusahaan untuk menjaga citra perusahaan dimata pelanggan. Pelayanan administrasi yang diberikan meliputi pelayanan administrasi pemasangan listrik baru, penambahan daya listrik dan sambungan listrik sementara. Keseluruhan dari proses pemberian pelayanan administrasi tersebut, memungkinkan kontak Antara pelanggan dan pegawai semakin banyak, sehingga pelayanan administrasi yang diberikan rentan terhadap komplain yang diberikan pelanggan akibat ketidakpuasan terhadap pelayanan yang diberikan. Ketidakpuasan pelanggan terhadap pelayanan yang diberikan, tentu saja akan berdampak buruk terhadap perusahaan. Oleh karena itu, untuk menghindari hal tersebut, maka perusahaan harus memberikan pelayanan yang berkualitas. Indikator yang digunakan untuk mengukur kualitas pelayanan adalah tangible, Reliability, Responsiveness, Assurance, Emphaty.
\end{abstract}

Kata kunci : Kualitas, Pelayanan, Administrasi 


\section{PENDAHULUAN}

Setiap manusia pada dasarnya membutuhkan pelayanan, bahkan dapat dikatakan bahwa pelayanan tidak dapat dipisahkan dengan kehidupan manusia. Pelayanan adalah proses pemenuhan kebutuhan melalui aktivitas orang lain secara langsung. Sedangkan, kualitas Pelayanan yang baik adalah kemampuan seseorang dalam memberikan pelayanan yang dapat diberikan kepuasan terhadap pelanggan dengan standar yang ditentukan. Masyarakat setiap waktu akan selalu menuntut pelayanan yang berkualitas dari pemerintah maupun pihak swasta. Oleh karena itu perusahaan yang ingin berkembang dan memiliki keunggulan perlu memperhatikan kualitas pelayanan.

Kualitas pelayanan sangat penting dikelola perusahaan dengan yang baik agar dapat memenuhi harapan pelanggan, karena masyarakat dengan berbagai macam kebutuhannya selalu mencari kepuasan dalam pemenuhan kebutuhan hidupnya. Jika masyarakat tidak mendapatkan kepuasan, maka akan menimbulkan persepsi negative akan pelayanan yang diberikan.

Instansi milik pemerintah ataupun swasta pada dasarnya menyediakan pelayanan untuk kepentingan masyarakat. Bentuk pelayanan juga berbeda-beda, seperti pelayanan administrasi, pelayanan komunikasi, pelayanan transportasi, pelayanan penerangan dan sebagainya. Namun pada dasanya segala jenis pelayanan memiliki tujuan yang sama yaitu untuk memenuhi kebutuhan dan kepuasan pelanggan. Pemerintah maupun swasta sebagai penyedia layanan publik harus bertanggung jawab dan terus berupaya untuk memberikan pelayanan yang terbaik demi peningkatan pelayanan publik. PT. PLN (Persero) Area Makassar
Selatan adalah salah satu sektor pelayanan publik memberikan berbagai jenis pelayanan. Salah satu ialah pelayanan administrasi. Bentuk pelayanan administrasi yang diberikan kepada pelanggan juga bermacammacam. Pelayanan administrasi pemasangan listrik, penambahan daya listrik, dan sambungan listrik sementara. Namun, penulis memfokuskan pada Kualitas Pelayanan Administrasi Pemasangan Listrik Baru (pelanggan baru), yang sering kali mendapatkan komplain dari pelanggan.

Bagi pelanggan baru yang akan mengajukan permohonan pemasangan listrik baru, tentu saja ada beberapa syarat administrasi yang harus dipenuhi. Pelanggan baru yang telah mengumpulkan kelengkapan administrasi yang diperlukan, akan disurvey oleh petugas lapangan untuk mendapatkan data teknis. Setelah survey dilakukan maka akan terbit surat jawaban, apakah permohonan disetujui atau tidak. Namun, rentang waktu survey dan penertiban Surat ijin penyambungan (SIP) yang terlalu lama, yang membuat pelanggan memberikan keluhan mengenai waktu pelayanan administrasi PT. PLN (Persero) Area Makassar Selatan.

Dari uraian tersebut, penulis tertarik untuk memilih judul " Kualitas Pelayanan Administrasi Pemasangan Listrik Baru Pada PT. PLN (Persero) Area Makassar Selatan".

\section{TINJAUAN PUSTAKA}

Menurut Wijaya (2011:4) "Kualitas adalah merupakan ukuran sampai sejauh mana produk atau jasa sesuai kebutuhan, Empati keinginan dan harapan para pelanggan. Kualitas didasarkan pada pengalaman aktual pelanggan terhadap produk atau jasa yang diukur 
berdasarkan persyaratan-persyaratan tersebut".

Sedangkan menurut Kotler (2009:17) kualitas didefinisikan sebagai keseluruhan ciri serta sifat barang dan jasa yang berpengaruh pada kemampuan memenuhi kebutuhan yang dinyatakan maupun yang tersirat.

Definisi dari kualitas memiliki banyak kriteria dan sangat bergantung pada konteksnya terutama jika dilihat dari sisi penilaian akhir konsumen dan definisi yang diberikan oleh berbagai ahli serta dari sudut pandang produsen sebagai pihak yang menciptakan kualitas. Konsumen dan produsen itu berbeda dan akan merasakan kualitas secara berbeda pula sesuai dengan standar kualitas yang dimiliki masing-masing.

Menurut Hasibuan

berpendapat tentang pelayanan yaitu "Pelayanan adalah kegiatan yang dilakukan seseorang atau sekelompok orang dengan landasan faktor material melalui prosedur dan dengan metode tertentu dalam rangka usaha memenuhi kepentingan orang lain sesuai dengan haknya".

Menurut Gronroos dalam buku Daryanto dan Setyobudi (2014: 135) dalam Rahmatriana (2014) : "Pelayanan adalah suatu aktivitas atau serangkaian aktivitas yang bersifat tidak kasat mata (tidak dapat diraba) yang terjadi sebagai akibat adanya interaksi antara konsumen dengan karyawan atau hal-hal lain yang disediakan oleh perusahaan pemberi pelayanan yang dimaksudkan untuk memecahkan masalah konsumen/pelanggan".

Ngalim Purwanto (2010: 1) : "Administrasi adalah suatu kegiatan atau usaha untuk membantu, melayani, mengarahkan, atau mengatur semua kegiatan di dalam mencapai suatu tujuan". jadi dapat disimpulkan bahwa administrasi adalah proses penyelenggaraan kegiatan yang ada dalam suatu organisasi yang menjunjung kegiatan-kegiatan organisasi dengan dilakukan dua orang atau lebih untuk mencapai sasaran yang telah ditetapkan sebelumnya, hal ini sangat jelas bahwa keterlibatan administrasi dapat memberikan tempat tersendiri dalam organisasi.

\section{METODE PENELITIAN}

Penelitian ini dilakukan di PT. PLN (Persero) Area Makassar Selatan yang beralamat di Jln. Letjend Hertasning Makassar berlokasi di Jalan Jenderal Sudirman No. 250 Makassar. Jenis data penelitian yang digunakan adalah data kualitatif yaitu data yang diperoleh dalam bentuk informasi baik itu secara lisan maupun tulisan. Penelitian ini menjelaskan dan menggambarkan Kualitas Pelayanan Administrasi Pemasangan Listrik Baru Pada PT. PLN (Persero) Area Makassar Selatan. Adapun teknik pengumpulan data yang digunakan dalam penelitian ini adalah: wawancara, studi kepustakaan, dokumentasi, dan kuesioner. Metode analisis data yang digunakan dalam penelitian ini menggunakan metode deskriptif kuantitatif.

\section{HASIL DAN PEMBAHASAN \\ 4.1 Hasil Penelitian}

Kualitas Pelayanan Administrasi Pemasangan Listrik Baru Pada PT.PLN (Persero) Area Makassar Selatan. Bebagai kemudahan yang ditawarkan PT.PLN (Persero) kepada pelanggan maupun calon pelanggan untuk mendapatkan pelayanan, dilakukan untuk memberikan pelayanan terbaik kepada pelanggan. Walaupun PT. PLN (Persero) sebagai satu-satunya perusahaan penyedia tenaga listrik di 
Indonesia, bukan berarti serta merta mengabaikan kepuasan pelanggannya. Anggapan bahwa masyarakat yang akan menggunakan listrik tidak akan beralih ke perusahaan lain kecuali ke PLN harus diantisipasi. Dari segi persaingan memang PLN belum atau tidak mendapat saingan dengan yang lain, tapi kepuasan pelanggan ini menjadi indikator kinerja perusahaan. Jika tingkat kepuasan pelanggan rendah berarti mempengaruhi kinerja perusahaan, dan tentunya citra perusahaan pun akan semakin buruk.

Pelayanan administrasi adalah salah satu jenis pelayanan yang diberikan PT.PLN (Persero) kepada pelanggan, yang tentu saja menjadi perhatian utama perusahaan untuk menjaga citra perusahaan dimata pelanggan. Pelayanan administrasi yang diberikan meliputi pelayanan administrasi pemasangan listrik baru, penambahan daya listrik dan sambungan listrik sementara. Keseluruhan dari proses pemberian pelayanan administrasi tersebut, memungkinkan kontak Antara pelanggan dan pegawai semakin banyak, sehingga pelayanan administrasi yang diberikan rentan terhadap komplain yang diberikan pelanggan akibat ketidakpuasan terhadap pelayanan yang diberikan. Ketidakpuasan pelanggan terhadap pelayanan yang diberikan, tentu saja akan berdampak buruk terhadap perusahaan. Oleh karena itu, untuk menghindari hal tersebut, maka perusahaan harus memberikan pelayanan yang berkualitas.

Untuk mengetahui kualitas pelayanan, khususnya pelayanan administrasi pelanggan baru yang diberikan oleh PT. PLN (Persero) Area Makassar Selatan, dapat dinilai dengan menggunakan Zeithmal dkk dalam Dewa (2011: 100) indikator kualitas pelayanan seperti yang dipaparkan pada sub-sub definisi operasional, sebagai berikut :

\section{a. Tangible (bukti langsung)}

Tangible (bukti langsung), artinya kualitas pelayanan yang berupa sarana fisik perkantoran ruang tunggu, dan lainnya. Indikator yang dinilai adalah : ketersediaan perlengkapan yang memadai, sistem sarana teknologi yang digunakan memadai, petugas menggunakan atribut PLN dalam pelayanan, dan tersedianya layanan informasi mendukung. Untuk mengetahui tanggapan responden tentang Tangible (bukti langsung) dalam pelayanan khususnya pada pemasangan listrik baru dapat dilihat pada tabel berikut ini :

Tabel 4.6 : Tanggapan Responden tentang Tangible (bukti langsung) pelayanan yang diterapkan pada kantor PT. PLN (Persero) Area Makassar Selatan

\begin{tabular}{|c|c|c|c|c|}
\hline Tanggapan Responden & Frekuensi & Bobot & F x B & Presentasi \\
\hline Sangat Setuju & $\mathbf{7}$ & 5 & $\mathbf{3 5}$ & $\mathbf{2 3 , 3 3 \%}$ \\
\hline Setuju & $\mathbf{8}$ & $\mathbf{4}$ & $\mathbf{3 2}$ & $\mathbf{2 6 , 6 7 \%}$ \\
\hline Ragu-ragu & $\mathbf{7}$ & $\mathbf{3}$ & $\mathbf{2 1}$ & $\mathbf{2 3 , 3 3 \%}$ \\
\hline Kurang Setuju & $\mathbf{6}$ & $\mathbf{2}$ & $\mathbf{1 2}$ & $\mathbf{2 0 \%}$ \\
\hline Tidak Setuju & $\mathbf{2}$ & $\mathbf{1}$ & $\mathbf{2}$ & $\mathbf{6 , 6 7 \%}$ \\
\hline Jumlah & $\mathbf{3 0}$ & $\mathbf{1 5}$ & $\mathbf{1 0 2}$ & $\mathbf{1 0 0 \%}$ \\
\hline Hasil Skor & \multicolumn{5}{|l}{$\mathbf{1 0 2}: 30 \times 100 \%=3,4$} \\
\hline
\end{tabular}

Sumber : Hasil Olahan Kuesioner 2017 
Berdasarkan tabel 4.6 di atas, maka diperoleh informasi bahwa dari 30 responden 7 atau 23,33\% diantaranya mengatakan sangat setuju lain halnya dengan 8 responden atau $26,67 \%$ mengatakan bahwa setuju dengan tangible (bukti langsung) pelayanan yang diterapkan pada kantor tersebut, namun ada 7 responden atau 23,33\% yang menyatakan mereka ragu-ragu juga ada 6 responden atau $20 \%$ yang mengatakan kurang setuju dan ada 2 responden atau $6,67 \%$ yang mengatakan tidak setuju.

Jika melihat data tersebut di atas menunjukkan bahwa diperoleh hasil skor yakni jumlah skor dibagi dengan jumlah frekuensi (jumlah responden) yaitu 102 : $30=3,4$. Hasil skor ini dibulatkan menjadi 3,0. Angka ini dapat dikatakan kategori Ragu-Ragu.

b. Reliability (keandalan)

Reliability (keandalan), artinya kemampuan dan keandalan untuk menyediakan pelayanan yang terpercaya. Indikator yang dinilai adalah : petugas pelayanan yang dijanjikan dengan segera, petugas pelayanan yang memuaskan, petugas menyedika informasi yang dibutuhkan, dan petugas menangani permasalahan sampai tuntas. Untuk mengetahui tanggapan responden tentang Reliability (keandalan) dalam pelayanan khususnya pada pemasangan listrik baru dapat dilihat pada tabel berikut ini :

Tabel 4.7 : Tanggapan Responden tentang Reliability (keandalan) pelayanan yang diterapkan pada kantor PT. PLN (Persero) Area Makassar Selatan

\begin{tabular}{|l|c|c|c|c|}
\hline \multicolumn{1}{|c|}{ Tanggapan Responden } & Frekuensi & Bobot & F x B & Presentasi \\
\hline Sangat Setuju & $\mathbf{1 2}$ & $\mathbf{5}$ & $\mathbf{6 0}$ & $\mathbf{4 0 \%}$ \\
\hline Setuju & $\mathbf{9}$ & $\mathbf{4}$ & $\mathbf{3 6}$ & $\mathbf{3 0 \%}$ \\
\hline Ragu-ragu & $\mathbf{6}$ & $\mathbf{3}$ & $\mathbf{1 8}$ & $\mathbf{2 0 \%}$ \\
\hline Kurang Setuju & $\mathbf{2}$ & $\mathbf{2}$ & $\mathbf{4}$ & $\mathbf{6 , 6 7 \%}$ \\
\hline Tidak Setuju & $\mathbf{1}$ & $\mathbf{1}$ & $\mathbf{1}$ & $\mathbf{3 , 3 3 \%}$ \\
\hline Jumlah & $\mathbf{3 0}$ & $\mathbf{1 5}$ & $\mathbf{1 1 9}$ & $\mathbf{1 0 0 \%}$ \\
\hline Hasil Skor & \multicolumn{5}{|c|}{$\mathbf{1 1 9 : 3 0 \times 1 0 0 \% = 3 , 9}$} \\
\hline
\end{tabular}

Sumber : Hasil Olahan Kuesioner 2017

Berdasarkan tabel 4.7 diatas, maka informasi yang didapatkan adalah dari 30 responden yang di berikan kuesioner tampaknya memberikan informasi yang sedikit berbeda diantaranya ada 12 responden atau $40 \%$ yang mengatakan sangat setuju dengan realibility (keandalan) yang diberikan pada kantor tersebut kemudian dengan jumlah yang berbeda yaitu 9 atau 30\% responden yang mengatakan setuju namun ada 6 responden atau $20 \%$ yang masih raguragu juga ada 2 atau $6,67 \%$ responden yang mengatakan kurang setuju dan 1 responden atau 3,33\% yang mengatakan tidak setuju. Jika melihat data tersebut di atas menunjukkan bahwa diperoleh hasil skor yakni jumlah skor dibagi dengan jumlah frekuensi (jumlah responden) yaitu 119 : $30=3,9$. Hasil skor ini dibulatkan menjadi 4,0. Angka ini dapat dikatakan kategori setuju.

c. Responsiveness (daya tanggap)

Responsiveness (daya tanggap), artinya kesanggupan untuk membantu dan menyediakan pelayanan secara cepat dan tepat, serta tanggap terhadap keinginan konsumen. Indikator yang dinilai adalah : petugas siap membantu pelanggan bila mengalami kesulitan, 
petugas cepat tanggap dalam melayani kepentingan pelanggan, petugas cepat tanggap dalam melayani permintaan pemasangan listrik baru, dan petugas bersedia mendengar keluh kesah pelanggan seputar masalah pemasangan listrik baru. Untuk mengetahui tanggapan responden tentang Responsiveness (daya tanggap) dalam pelayanan khususnya pada pemasangan listrik baru dapat dilihat pada table berikut ini :

Tabel 4.8 : Tanggapan Responden tentang Responsiveness (daya tanggap) pelayanan yang diterapkan pada kantor PT. PLN (Persero) Area Makassar Selatan

\begin{tabular}{|l|c|c|c|c|}
\hline \multicolumn{1}{|c|}{ Tanggapan Responden } & Frekuensi & Bobot & F x B & Presentasi \\
\hline Sangat Setuju & $\mathbf{1 5}$ & $\mathbf{5}$ & $\mathbf{7 5}$ & $\mathbf{5 0 \%}$ \\
\hline Setuju & $\mathbf{9}$ & $\mathbf{4}$ & $\mathbf{3 6}$ & $\mathbf{3 0 \%}$ \\
\hline Ragu-ragu & $\mathbf{4}$ & $\mathbf{3}$ & $\mathbf{1 2}$ & $\mathbf{1 3 , 3 3 \%}$ \\
\hline Kurang Setuju & $\mathbf{2}$ & $\mathbf{2}$ & $\mathbf{4}$ & $\mathbf{6 , 6 7 \%}$ \\
\hline Tidak Setuju & $\mathbf{0}$ & $\mathbf{1}$ & $\mathbf{0}$ & $\mathbf{0} \%$ \\
\hline Jumlah & $\mathbf{3 0}$ & $\mathbf{1 5}$ & $\mathbf{1 2 7}$ & $\mathbf{1 0 0 \%}$ \\
\hline Hasil Skor & \multicolumn{5}{|c|}{$\mathbf{1 2 7 : 3 0 \times 1 0 0 \% = 4 , 2}$} \\
\hline
\end{tabular}

Sumber : Hasil Olahan Kuesioner 2017

Berdasarkan tabel 4.8 diatas, maka informasi yang didapatkan adalah dari 30 responden yang di berikan kuesioner tampaknya memberikan informasi yang sedikit berbeda diantaranya ada 15 responden atau $50 \%$ yang mengatakan sangat setuju dengan responsiveness (daya tanggap) yang diberikan pada kantor tersebut kemudian dengan jumlah yang berbeda yaitu 9 atau 30\% responden yang mengatakan setuju namun ada 4 responden atau 13,33\% yang masih ragu-ragu juga ada 2 atau $6,67 \%$ responden yang mengatakan kurang setuju dan 0 responden atau $0 \%$ yang mengatakan tidak setuju.

Jika melihat data tersebut di atas menunjukkan bahwa diperoleh hasil skor yakni jumlah skor dibagi dengan jumlah frekuensi (jumlah responden) yaitu 127 : $30=4,2$. Hasil skor ini dibulatkan menjadi 4. Angka ini dapat dikatakan kategori setuju.

\section{d. Assurance (jaminan)}

Assurance (jaminan), artinya kemampuan dan keramahan serta sopan santun pegawai dalam menyakinkan dan menumbuhkan kepercayaan konsumen. Indikator yang dinilai adalah : petugas sopan dalam melayani pelanggan, petugas terampil dalam melayani pelanggan, petugas memiliki pengetahuan yang luas mengenai pemasangan listrik baru, dan petugas menjalankan tugasnya sesuai dengan SOP (Standard Operational Procedure). Untuk mengetahui tanggapan responden tentang Assurance (jaminan) dalam pelayanan khususnya pada pemasangan listrik baru dapat dilihat pada table berikut ini : 
Tabel 4.9 : Tanggapan Responden tentang Assurance (jaminan) pelayanan yang diterapkan pada kantor PT. PLN (Persero) Area Makassar Selatan

\begin{tabular}{|l|c|c|c|c|}
\hline \multicolumn{1}{|c|}{ Tanggapan Responden } & Frekuensi & Bobot & F x B & Presentasi \\
\hline Sangat Setuju & $\mathbf{1 4}$ & $\mathbf{5}$ & $\mathbf{7 0}$ & $\mathbf{4 6 , 6 5 \%}$ \\
\hline Setuju & $\mathbf{1 2}$ & $\mathbf{4}$ & $\mathbf{4 8}$ & $\mathbf{4 0 \%}$ \\
\hline Ragu-ragu & $\mathbf{2}$ & $\mathbf{3}$ & $\mathbf{6}$ & $\mathbf{6 , 6 7 \%}$ \\
\hline Kurang Setuju & $\mathbf{2}$ & $\mathbf{2}$ & $\mathbf{4}$ & $\mathbf{6 , 6 7 \%}$ \\
\hline Tidak Setuju & $\mathbf{0}$ & $\mathbf{1}$ & $\mathbf{0}$ & $\mathbf{0} \%$ \\
\hline Jumlah & $\mathbf{3 0}$ & $\mathbf{1 5}$ & $\mathbf{1 2 8}$ & $\mathbf{1 0 0 \%}$ \\
\hline Hasil Skor & \multicolumn{5}{|c|}{$\mathbf{1 2 8 : 3 0 \times 1 0 0 \% = 4 , 2}$} \\
\hline
\end{tabular}

Sumber : Hasil Olahan Kuesioner 2017

Berdasarkan tabel 4.9 diatas, maka informasi yang didapatkan adalah dari 30 responden yang di berikan kuesioner tampaknya memberikan informasi yang sedikit berbeda diantaranya ada 14 responden atau $46,65 \%$ yang mengatakan sangat setuju dengan assurance (jaminan) yang diberikan pada kantor tersebut kemudian dengan jumlah yang berbeda yaitu 12 atau $40 \%$ responden yang mengatakan setuju namun ada 2 responden atau $6,67 \%$ yang masih ragu-ragu juga ada 2 atau $6,67 \%$ responden yang mengatakan kurang setuju dan 0 responden atau $0 \%$ yang mengatakan tidak setuju.

Jika melihat data tersebut di atas menunjukkan bahwa diperoleh hasil skor yakni jumlah skor dibagi dengan jumlah frekuensi (jumlah responden) yaitu 128 :
$30=4,1$. Hasil skor ini dibulatkan menjadi 4. Angka ini dapat dikatakan kategori setuju.

e. Emphaty (empati)

Emphaty (empati), artinya sikap tegas tetapi penuh perhatian dari pegawai terhadap konsumen. Indikator yang dinilai adalah : petugas mengutamakan kepentingan pelanggan, petugas mau memberi perhatian kepada pelanggan, petugas memahami dan tanggap akan kebutuhan spesifik pelanggan, dan petugas melakukan komunikasi yang baik dengan para pelanggan. Untuk mengetahui tanggapan responden tentang Emphaty (empati) dalam pelayanan khususnya pada pemasangan listrik baru dapat dilihat pada table berikut ini :

Tabel 4.10 : Tanggapan Responden tentang Emphaty (empati) pelayanan yang diterapkan pada kantor PT. PLN (Persero) Area Makassar Selatan

\begin{tabular}{|l|c|c|c|c|}
\hline \multicolumn{1}{|c|}{ Tanggapan Responden } & Frekuensi & Bobot & F x B & Presentasi \\
\hline Sangat Setuju & $\mathbf{1 2}$ & $\mathbf{5}$ & $\mathbf{6 0}$ & $\mathbf{4 0 \%}$ \\
\hline Setuju & $\mathbf{1 1}$ & $\mathbf{4}$ & $\mathbf{4 4}$ & $\mathbf{3 6 , 6 7 \%}$ \\
\hline Ragu-ragu & $\mathbf{4}$ & $\mathbf{3}$ & $\mathbf{1 2}$ & $\mathbf{1 3 , 3 3 \%}$ \\
\hline Kurang Setuju & $\mathbf{2}$ & $\mathbf{2}$ & $\mathbf{4}$ & $\mathbf{6 , 6 7 \%}$ \\
\hline Tidak Setuju & $\mathbf{1}$ & $\mathbf{1}$ & $\mathbf{1}$ & $\mathbf{3 , 3 3 \%}$ \\
\hline Jumlah & $\mathbf{3 0}$ & $\mathbf{1 5}$ & $\mathbf{1 2 1}$ & $\mathbf{1 0 0 \%}$ \\
\hline Hasil Skor & \multicolumn{5}{|c|}{$\mathbf{1 2 1 : 3 0 \times 1 0 0 \% = 4 , 0}$} \\
\hline
\end{tabular}

Sumber : Hasil Olahan Kuesioner 2017

Berdasarkan tabel 4.10 diatas, maka informasi yang didapatkan adalah dari 30 responden yang di berikan kuesioner tampaknya memberikan informasi yang sedikit berbeda diantaranya ada 12 responden atau $40 \%$ 
yang mengatakan sangat setuju dengan emphaty (empati) yang diberikan pada kantor tersebut kemudian dengan jumlah yang berbeda yaitu 11 atau 36,67\% responden yang mengatakan setuju namun ada 4 responden atau 13,33\% yang masih ragu-ragu juga ada 2 atau $6,67 \%$ responden yang mengatakan kurang setuju dan 1 responden atau 3,33\% yang mengatakan tidak setuju.

Jika melihat data tersebut di atas menunjukkan bahwa diperoleh hasil skor yakni jumlah skor dibagi dengan jumlah frekuensi (jumlah responden) yaitu 121 : $30=4,0$. Hasil skor ini dibulatkan menjadi 4. Angka ini dapat dikatakan kategori setuju.

Tabel 4.11 : Rekapitulasi Tanggapan Responden Tentang Kualitas Prosedur Pelayanan Administrasi Pemasangan Listrik Baru pada PT. PLN (Persero) Area Makassar Selatan.

\begin{tabular}{|c|l|c|c|}
\hline No. & \multicolumn{1}{|c|}{ Indikator Pelayanan } & Hasil Skor & Keterangan \\
\hline 1 & Tangible (bukti langsung) & 3,4 & Ragu-ragu \\
\hline 2 & Realibility (keandalan) & 3,9 & Setuju \\
\hline 3 & Responsiveness (daya tanggap) & 4,2 & Setuju \\
\hline 4 & Assurance (jaminan) & 4,2 & Setuju \\
\hline 5 & Emphaty (empati) & 4,0 & Setuju \\
\hline Jumlah Hasil Skor & $\mathbf{1 9 , 7}$ & \\
\hline Rata-rata Skor & $\mathbf{3 , 9 4}$ & Setuju \\
\hline
\end{tabular}

Sumber : Hasil Olahan Kusioner 2017

Berdasarkan data rekapitulasi yang diperoleh dari 30 responden maka didapatkan rata-rata skor yang berada pada angka 3,94 yang dapat dikategorikan Setuju. Sehigga dapat ditarik kesimpulan bahwa Kualitas Pelayanan Administrasi Pemasangan Listrik Baru pada PT. PLN (Persero) Area Makassar Selatan sudah memuaskan para pelanggan.

\subsection{Kendala-kendala yang dihadapi dalam memberikan Kualitas Pelayanan Administrasi Pemasangan Listrik Baru pada PT.PLN (Persero) Area Makassar Selatan}

Berdasarkan hasil wawancara dengan junior administrasi pelayanan pelanggan PLN Area Makassar Selatan, terdapat bebarapa kendala-kendala yang dihadapi dalam memberikan pelayanan administrasi kepada pelanggan baru PLN Area Makassar Selatan: a. Calon pelanggan baru yang masuk dalam daftar potensi pasar

Permohonan pelanggan baru yang telah disertai dengan kelengkapan administrasi akan segera dilakukan survey ke lokasi bangunan yang akan dilakukan penyambungan listrik. PLN akan menerbitkan surat ijin penyambungan, apabila hasil survey di lokasi dinilai layak, seperti jarak Antara bangunan yang akan dilistriki dengan jaringan atau dengan rumah terdekat pelanggan PLN dinilai layak.

PLN akan melakukan penangguhan denga memasukkan calon pelanggan ke daftar potensi pasar, apabila hasil survey dinilai tidak layak. Hal ini akan menyebabkan pelanggan tidak dapat melakukan proses untuk pemasangan listrik baru selama beberapa waktu yang telah ditentukan. Memasukka calon pelanggan ke daftar potensi pasar, menjadi kendala dalam memberikan 
pelayanan administrasi untuk pelanggan baru.

Prosedur yang tidak banyak dikenal oleh pelanggan, menyebabkan mereka memberikan komplain penangguhan yang dilakukan PLN. Hanya beberapa pelanggan yang dapat mengerti dan menerima keputusan penagguhan yang dilakukan akibat analisis yang tidak layak. Namun, pihak PLN berusaha untuk menanggulangi hal tersebut, dengan memberikan penjelasan yang dapat di mengerti pelanggan mengenai penangguhan yang dilakukan.

b. Alokasi anggaran besar untuk pelanggan industri

Pelanggan industri ialah pelanggan listrik denga daya listrik tinggi, mulai dari industri kecil, menengah, sampai dengan industri besar dengan daya listrik diatas 30.000 Kva. Daya listrik tinggi oleh pelanggan industri, tentu saja memutuhkan alokasi biaya yang besar untuk pemasangan listrik baru. Adanya alokasi yang besar terkadanga membuat waktu penyalasaian pemasangan listrik baru menjadi lebih lama dibandingkan dengan pelanggan rumah tangga, hal ini diakibatkan anggaran yang diperoleh dari pusat tidak mampu memenuhi kebutuhan industry, sehingga dibutuhkan proses permintaan anggaran ke kantor pusat terlebih dahulu untuk emenuhi kebutuhan industry. Alokasi anggaran yang besar menjadi kendala bagi PLN karena tidak dapat memberikan pelayanan dalam waktu singkat kepada pelanggan industry.

\section{c. Sertifikat Laik Operasi}

Sertifikat Laik Operasi (SLO) adalah sertifikat yang dikeluarkan oleh Lembaga Inspeksi Teknik, sesuai denagn Undang-Undang No 30 tahun 2009 tentang ketenagalistrikan pasal 44 ayat 4 maka setiap instalasi tenaga listrik yang beroperasi wajib memiliki sertifikat laik operasi. Calon pelanggan yan akan melakukan pemasangan listrik baru, harus disertai dengan sertifikat laik operasi, yang diterbitkan lembaga yang melakukan pengujian terhadap pemasangan instalasi listrik dirumah pelanggan.

Penandatangan SPJBTL (Surat Perjanjian Jual Beli Tenaga Listrik) adalah tahap terakhir yang dilalui pelanggan sebelum listrik resmi terpasang. Penndatangan SPJBTL hanya dapat dilakukn apabila seluruh syarat administrasi telah dipenuhi. Sertifikat laik operasi (SLO) merupakan salah satu syarat administrasi yang harus dipenuhi. Namun, beberapa pelanggan masih saja tidak memiliki SLO ketika akan melakukan penandatangan SPJBTL.

Pelanggan yang tidak memiliki SLO maka akan diarahkan pegawai untuk melengkapi SLO dari lembaga inspeksi teknik, sebelum melanjutkan penandatangan SPJBTL. Hal ini mengakibatkan rentang waktu penyelesaian pemasangan listrik baru, menjadi lebih lama dari yang ditentukan sebelumnya.

\section{SIMPULAN}

Berdasarkan hasil pembahasan di atas, Maka dapat disimpulkan dua hal sebagai berikut:

5.1 Kualitas pelayanan administrasi PLN Area Makassar Selatan yang meliputi pendaftaran dan kelengkapan administrasi, survey lapangan, penerbit surat ijin penyambunya (SIP), penerbitan surat perjanjian jual beli tenaga listrik (SPJBTL), dan penyambungan, dapat dinilai menggunakan indikator kualitas pelayanan yaitu tangible, reliability, responsiveness, assurance, dan emphaty. 
5.2 Berdasarkan hasil observasi dan wawancara dapat disimpulkan bahwa, pelayanan administrasi pelanggan baru yang diberikan PT. PLN (Persero) Area Makassar Selatan adalah baik. Hal ini dapat dilihat dari hasil kuesioner terhadap responden, yang secara keseluruhan lebih banyak memberi tanggapan positif terhadap kualitas pelayanan administrasi PT. PLN (Persero) Area Makassar Selatan sudah memuaskan.

5.3 Kendala-kendala yang dihadapi PLN Area Makassar Selatan dalam memberikan pelayanan administrasi pelanggan baru yaitu, menghadapi keluhan pelanggan yang masuk dalam daftar potensi pasar akibat hasil survey lokasi dinilai tidak layak. Alokasi biaya yang besar untuk pelanggan industri, yang membutuhkan rentang waktu penyelesaian yang lebih lama dibandingkan dengan pelanggan rumah tangga. Kekurang pahaman pelanggan terhadap sertifikat laik operasi, yang menjadi salah satu syarat administrasi yang harus dipenuhi calon pelanggan. Oleh karena itu rentang waktu penyelesaian pemasangan listrik baru menjadi lebih lama.

\section{Referensi}

\section{a. Buku}

Barata, Atep. 2004. Dasar - Dasar Pelayanan Prima. Jakarta: Elex Media Komputindo.

Dewa, Jufri. 2011. Hukum Administrasi Negara dalam Perspektif Pelayanan Publik. Kendari: Unhalu Press.

Hasibuan, Malayu. 2007. Dasar - Dasar Perbankan. Jakarta: PT. Bumi Aksara.
Moenir, H.A.S. 2010. Manajemen Pelayanan Umum di Indonesia. Jakarta: Bumi Aksara.

Moleong. 2005. Metodologi Kualitatif Edisi Revisi. Bandung: PT Remaja Rosdakarya.

Moleong . 2009. Metode Peneitian Kualitatif. Bandung : PT. Remaja Rosdakarya.

Pasolong, Harbani. 2011. Teori Administrasi Publik. Bandug: Alfabeta.

Pasolong, Harbani . 2012. Metode Penelitian Administrasi Publik. Bandung: Alfabeta.

Rahmayanty, Nina. 2012. Manajemen Pelayanan prima. Yogyakarta: Graha Ilmu.

Ridwan, Juniarso dan Achmad Sodik Sudrajat. 2012. Hukum Administrasi Negara Ddan Kebijakan Pelayanan Publik. Bandung: Nuansa.

Sinamo, Nomensen. 2010. Hukum Adminitrasi Negara, Jakarta: Jala Permata Aksara.

Sugiyono. 2009. Metode Penelitian Kuantitatif,Kualitatif dan $R \& D$. Bandung: Alfabeta.

Syafiie, Inu Kencana. 2006. Ilmu Administrasi Publik. Jakarta: Rineke Cipta.

Daryanto, 2011. Konsep Administrasi Pendidikan. (Online). (http://eenhenrayani.blogspot.co.id/2013/04 /konsep-administrasipendidikan.html, diakses tanggal 5 maret 2017)

Napitulu, Paimin. 2007. Pelayanan Gangguan dan Pemeliharaan Disribusi,(Online), (http://ophardistsopang.blogspot. com/p/sop-pasang-baru.html, diakses 15 Maret 2017).

Ngalim Purwanto, 2010. Konsep Administrasi Pendidikan. (Online). 
(http://een-

henrayani.blogspot.co.id/2013/04

/konsep-administrasi-

pendidikan.html, diakses tanggal 5

maret 2017)

Rahmatriana, Daryanto dan Setyobudi.

2014. Kualitas Pelayanan. (Online).

(http://y-share-

it.blogspot.co.id/2015/05/kualitas

-pelayanan.html, diakses tanggal 5

Maret 2017)

Susilawati, Buchari Alma. 2011. Kualitas

Pelayanan. (Online). (http://y-

share-

it.blogspot.co.id/2015/05/kualitas

-pelayanan.html, diakses tanggal 5

Maret 2017)

Selvi Mirthawati Setyorini. 2016. Kualitas

Pelayanan Pasang Baru Listrik oleh

PT.PLN (Persero) di Kecamatan

Kalisat.

Wiwiek Suita. 2015. Pelayanan

Administrasi pada PT. PLN

(Persero) Rayon Utara. 